\title{
Economic Growth and International Trade Effect on Fiscal Revenue Empirical Research in China Area
}

\author{
Zhang Hang, Liu Yun \\ Accounting, Ning Bo Da Hong Ying University, Ningbo, China \\ Email address: \\ 87377887@qq.com (Zhang Hang), ly2005112@163.com (Liu Yun)
}

\section{To cite this article:}

Zhang Hang, Liu Yun. Economic Growth and International Trade Effect on Fiscal Revenue Empirical Research in China Area. Journal of Finance and Accounting. Vol. 5, No. 3, 2017, pp. 96-101. doi: 10.11648/j.jfa.20170503.12

Received: January 17, 2017; Accepted: May 4, 2017; Published: May 10, 2017

\begin{abstract}
International trade to the trading countries have mutual effect, Import and export trade for the realization of economic output and the growth of the regional financial revenue plays an important role. This article selects 2015 provinces in China import and export trade, GDP and fiscal revenue for the variable cross section data, a regression model for related elements were analyzed, and the various provinces and cities of fiscal revenue import and export trade, GDP growth elasticity coefficient, to various provinces and cities to promote economic development and expand import and export trade, achieve financial steady growth and provide data for development of elastic dynamics theory. The results of this study was to comprehensive model, that is, straight line and curve of mixed structure model, simulation level high reliable degree, can be a reference for prediction and decision-making.
\end{abstract}

Keywords: Import and Export Trade, Gross Domestic Product, Fiscal Revenue, Modulus of Elasticity

\section{Preface}

Production for the main indicators of economic development; With import and export trade is the main indicators to realize output value compensation and value added; Revenue is the economic development and trade of added value. This article attempts to import and export trade and economic output for the role of fiscal revenue, to explain the economic and trade, interprets the economic and trade on the regional financial resources and the significance of national greatness.

Can not only bring tariffs, import trade sales link of turnover tax, can also ease the shortage of resources, etc., make up the blank in China, short board, meet domestic demand; Export trade, but also sales proceeds of Chinese economy, achieve cost recovery and profit, realize the procurement, production, sales and distribution virtuous circle of economic activities. Import and export trade is our country economy into the world economy, promoting the development of their own. Reform, open, open, it is almost 30 years in our country, the key to the economic rapid development. This article attempts to various provinces and cities in our country finance income data section in 2015 as the dependent variable, with import and export trade as control variable, and participation marks the domestic production situation of the regional economic development as the independent variables, the analysis of import and export trade and economic output of provinces and cities, and the relationship between local fiscal revenue, and then reveals the import and export trade and fiscal revenue, the number of interdependent relationship between economic output, so as to promote the import and export trade and fiscal sustained economic coordinated development.

This article assumes that the import and export trade in addition to bring fiscal taxation, can indirectly promote the regional economic development bring fiscal revenue, the income is associated with the import and export trade, between the quantitative rule; And fiscal revenue mainly through the realization of economic value, and become the endogenous variable of economic output, and therefore choose to import and export trade and regional economic output to explain financial income, its theoretical conception, assume that exist in the three indexes quantitative dependent rule, which can use the empirical method is verified, you can find the dependent model architecture. Look forward to the results of the study, analysis of gain and loss, import and export trade for scientific budgeting, coordination of regional economic development, provide oversized and associated performance evaluation. 
2. Model Index Selection and Assumptions

(1). This paper selected indicators to: Local finance income: LFI said;
Import and export trade volume: IET said; The positively related to the local finance income;

Gross domestic product (GDP): Jane in GDP; Positive correlation with the local finance income.

Table 1. Provinces and cities in 2015 revenue and import and export trade and economic output index.

\begin{tabular}{|c|c|c|c|c|}
\hline number & Provinces Cities & LFI & IET & GDP \\
\hline 1 & GuangDong & 9364.8 & 1022870000 & 72812.6 \\
\hline 2 & JiangSu & 8028.6 & 545610000 & 70116.4 \\
\hline 3 & ShanDong & 5529.3 & 241750000 & 63002.3 \\
\hline 5 & ZheJiang & 4809.5 & 347340000 & 42886.5 \\
\hline 6 & BeiJing & 4723.9 & 319620000 & 22968.6 \\
\hline 7 & SiChuan & 3349.2 & 51470000 & 30103.1 \\
\hline 9 & HuBei & 3005.4 & 45600000 & 29550.2 \\
\hline 10 & TianJin & 2667 & 114350000 & 16538.2 \\
\hline 11 & HeBei & 2648.5 & 51480000 & 29806.1 \\
\hline 12 & FuJian & 2544.1 & 169360000 & 25979.8 \\
\hline 13 & HuNan & 2515.8 & 29330000 & 29047.2 \\
\hline 14 & AnHui & 2454.2 & 47970000 & 22005.6 \\
\hline 15 & JiangXi & 2165.5 & 42470000 & 16723.8 \\
\hline 16 & ChongQing & 2155.1 & 74480000 & 15719.7 \\
\hline 18 & ShanXi-1 & 2059.9 & 30500000 & 18171.9 \\
\hline 19 & NeiMeng & 1963.5 & 12750000 & 18032.8 \\
\hline 20 & YunNan & 1808.1 & 24520000 & 13717.9 \\
\hline 21 & ShanXi-2 & 1642.2 & 14720000 & 12802.6 \\
\hline 22 & GuangXi & 1515.1 & 51260000 & 16803.1 \\
\hline 23 & GuiZhou & 1503.3 & 12220000 & 10502.6 \\
\hline 24 & XinJiang & 1331 & 19680000 & 9324.8 \\
\hline 25 & JiLin & 1229.3 & 18940000 & 14274.1 \\
\hline 26 & HeiLongJiang & 1165.2 & 20990000 & 15083.7 \\
\hline 27 & $\mathrm{GanSu}$ & 743.9 & 8000000 & 6790.3 \\
\hline 28 & HaiNan & 627.7 & 13960000 & 3702.8 \\
\hline 29 & NingXia & 373.7 & 3790000 & 2911.8 \\
\hline 30 & QingHai & 267.1 & 1930000 & 2417.1 \\
\hline 31 & XiZang & 137.1 & 910000 & 1026.4 \\
\hline
\end{tabular}

Data source: with dispatch. Data analysis tool: the excel version.

(2). The model structure is:

$$
\mathrm{LIF}=\beta_{0}+\beta_{1} \mathrm{IET}+\beta_{2} G D P
$$

Selects 2015 provinces in China import and export trade, GDP and fiscal revenue for the variable cross section data, a regression model for related elements were analyzed.

\section{The Empirical Analysis}

Table 2. Descriptive statistics.

\begin{tabular}{|c|c|c|c|c|c|}
\hline LIF & & IFT & & GDP & \\
\hline Average & 2676.861 & Average & $1.28 \mathrm{E}+08$ & Average & 23340.02 \\
\hline Standard error margin & 383.8941 & Standard error margin & 38832540 & Standard error margin & 3270.992 \\
\hline Median & 2155.1 & Median & 45600000 & Median & 18032.8 \\
\hline Many numbers & \#N/A & Many numbers & $\# \mathrm{~N} / \mathrm{A}$ & Many numbers & $\# \mathrm{~N} / \mathrm{A}$ \\
\hline Sigma & 2137.432 & Sigma & $2.16 \mathrm{E}+08$ & Sigma & 18212.11 \\
\hline Variance & 4568614 & Variance & $4.67 \mathrm{E}+16$ & Variance & $3.32 \mathrm{E}+08$ \\
\hline Feng degree & 2.810795 & Feng degree & 9.532187 & Feng degree & 2.000398 \\
\hline Be partial to a degree & 1.619769 & Be partial to a degree & 2.888454 & Be partial to a degree & 1.452759 \\
\hline District & 9227.7 & District & $1.02 \mathrm{E}+09$ & District & 71786.2 \\
\hline Is minimum to be worth & 137.1 & Is minimum to be worth & 910000 & Is minimum to be worth & 1026.4 \\
\hline The biggest value & 9364.8 & The biggest value & $1.02 \mathrm{E}+09$ & The biggest value & 72812.6 \\
\hline Sue for peace & 82982.7 & Sue for peace & $3.96 \mathrm{E}+09$ & Sue for peace & 723540.7 \\
\hline Prognosticate a number & 31 & Prognosticate a number & 31 & Prognosticate a number & 31 \\
\hline Biggest(1) & 9364.8 & Biggest(1) & $1.02 \mathrm{E}+09$ & Biggest(1) & 72812.6 \\
\hline Minimum(1) & 137.1 & Minimum(1) & 910000 & Minimum(1) & 1026.4 \\
\hline Believe a degree $(95.0 \%)$ & 784.0162 & Believe a degree $(95.0 \%)$ & 79306627 & Believe a degree $(95.0 \%)$ & 6680.256 \\
\hline
\end{tabular}


Table 3. Mutual coefficient.

\begin{tabular}{llll}
\hline & Row 1 & Row 2 & Row 3 \\
\hline Row 1 & 1 & & \\
Row 2 & 0.92029 & 1 & \\
Row 3 & 0.919704 & 0.780982 & 1 \\
\hline
\end{tabular}

Table 4. The regression statisticses.

\begin{tabular}{ll}
\hline Multiple R & 0.974927 \\
R Square & 0.950482 \\
Adjusted R Square & 0.946945 \\
Standard error margin & 492.3282 \\
Prognosticate a value & 31 \\
\hline
\end{tabular}

Overall simulation level has reached more than $95 \%$, the student $\mathrm{T}$ statistic detection is significant

Table 5. Regression coefficient.

\begin{tabular}{llllllll}
\hline & Coefficients & $\begin{array}{l}\text { Standard error } \\
\text { margin }\end{array}$ & t Stat & P-value & $\begin{array}{l}\text { Lower } \\
\mathbf{9 5 \%}\end{array}$ & Upper 95\% & $\begin{array}{l}\text { Next limit } \\
\mathbf{9 5 . 0 \%}\end{array}$ \\
\hline Intercept & 611.9915 & 156.779 & 3.90353 & 0.00054 & 290.844 & 933.139 \\
X Variable 1 & $5.12 \mathrm{E}-06$ & $6.66 \mathrm{E}-07$ & 7.69162 & $2.23 \mathrm{E}-08$ & $3.76 \mathrm{E}-06$ & $6.48 \mathrm{E}-06$ & 290.844 \\
X Variable 2 & 0.060469 & 0.00790 & 7.65188 & $2.46 \mathrm{E}-08$ & 0.04428 & 0.07666 & $3.76 \mathrm{E}-06$ \\
\hline
\end{tabular}

\section{Two-Factor Structure Relationship Test}

(1). The import and export trade on the relationship between the fiscal reven

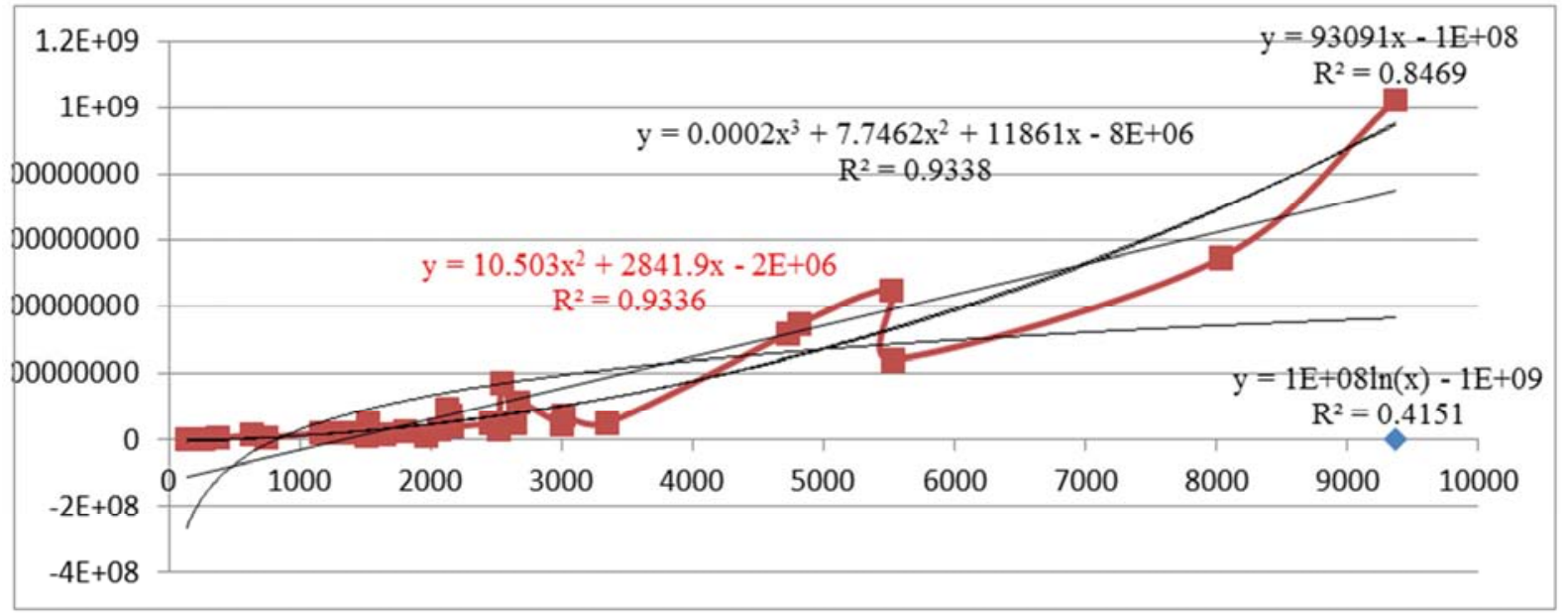

Figure 1. Import and export trade and fiscal revenue trend chart.

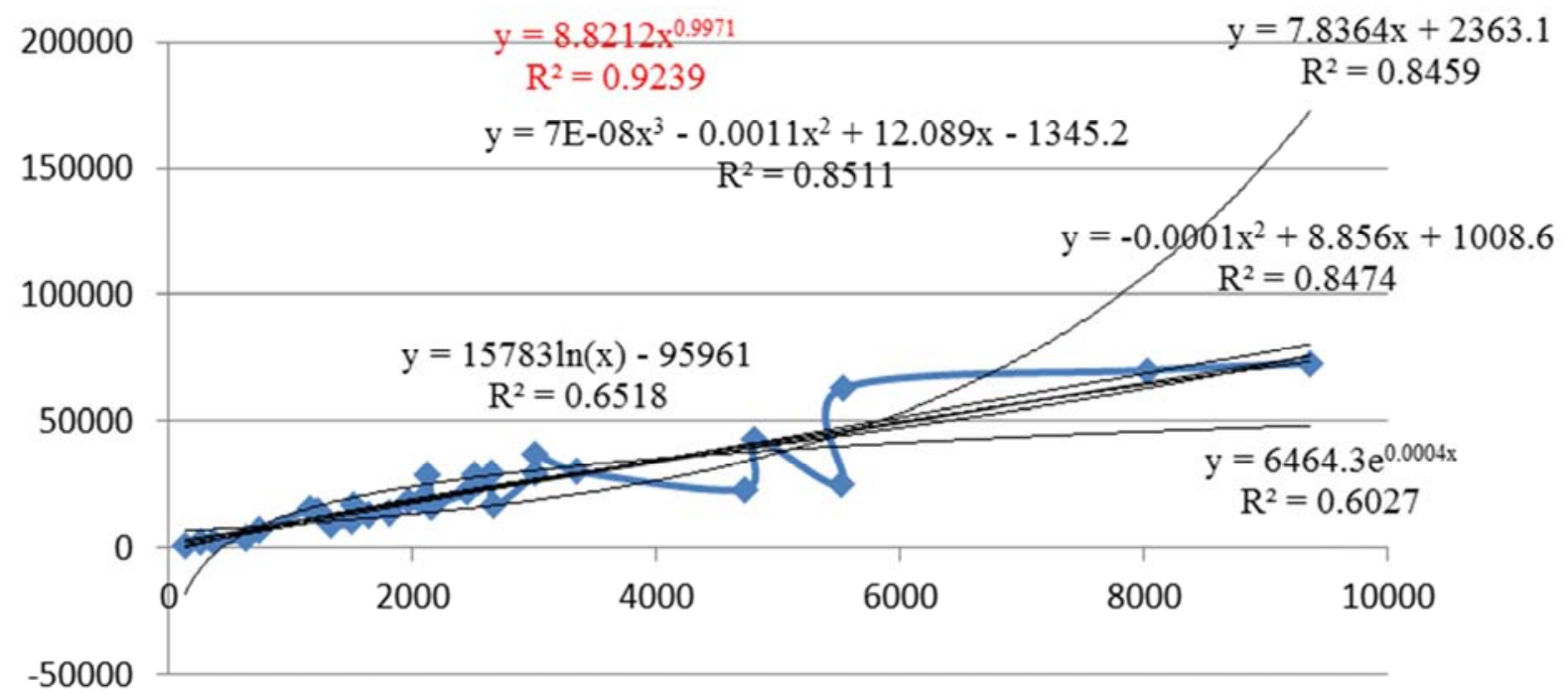

Figure 2. The relationship between GDP and fiscal revenue trend chart. 


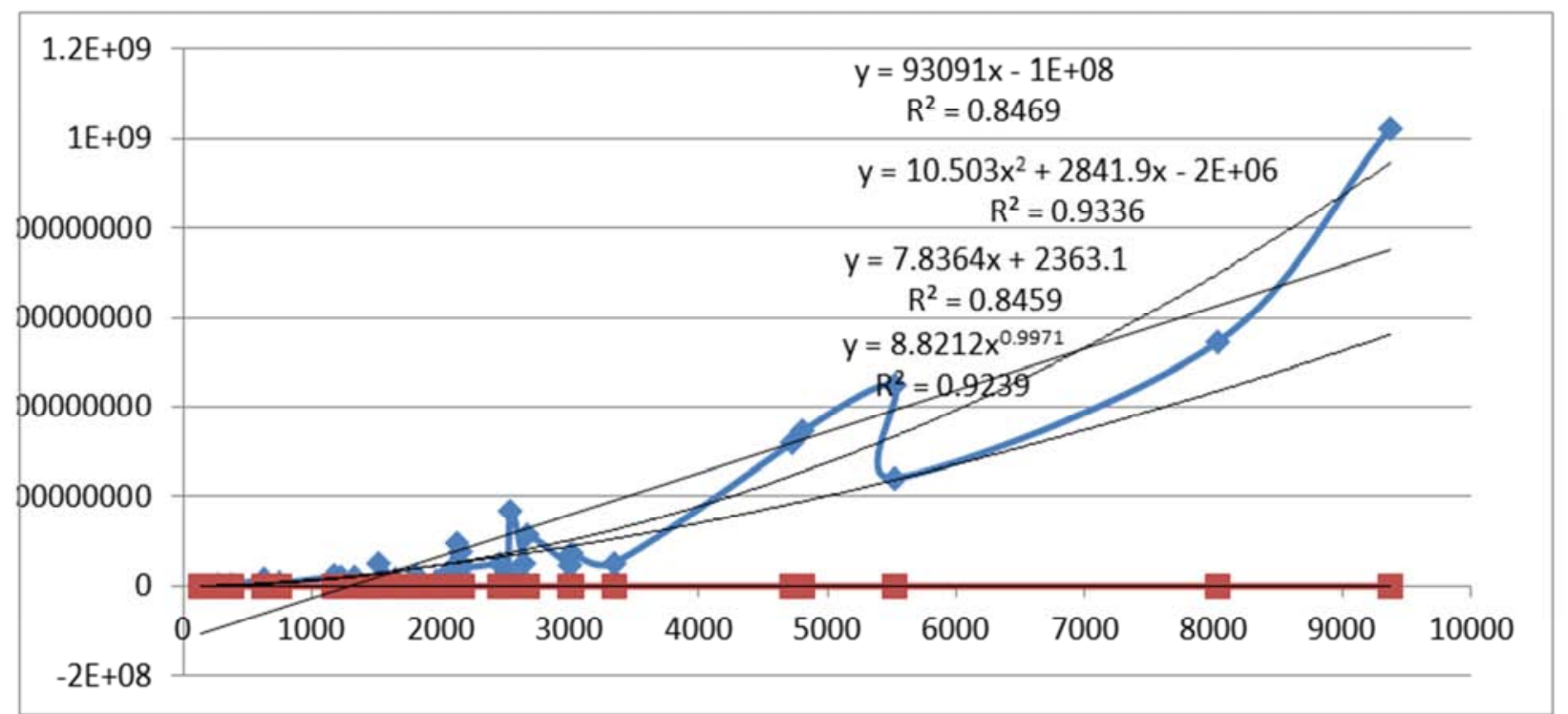

Figure 3. Import and export trade and GDP comprehensive relations trend chart.

In four kinds of test model, the quadratic term and three times the highest overall simulation, a secondary item analogue.

(2). The resolution on the relationship between the fiscal revenue in gross domestic product (GDP)

In the resolution of the relationship of fiscal income, GDP in six kinds of structure model test, we found that the optimal model structure for bottom is output to power structure model for the optimal.

(3). Comprehensive model of the structure

According to above stability test, we finally reached the comprehensive regression model, regression model for straight line and curve mixed structure model, and compared with linear, comprehensive regression model of the overall simulation level to $96 \%$, $\mathrm{P}$ value coefficient of regression model of statistics test (including the intercept) are 0.001 (import and export of quadratic term coefficient of significance level is $2 \%$ ) significantly above, shows that comprehensive mixed regression model is import and export trade and the value of the optimal model of fiscal revenue.

Table 6. The regression statisticses.

\begin{tabular}{ll}
\hline Multiple R & 0.982438 \\
R Square & 0.965185 \\
Adjusted R Square & 0.961316 \\
Standard error margin & 420.3946 \\
Prognosticate a value & 31 \\
\hline
\end{tabular}

Table 7. The variance is analytical.

\begin{tabular}{llllll}
\hline & df & SS & MS & F & Significance F \\
\hline The regression is analytical & 3 & $1.32 \mathrm{E}+08$ & 44095555 & 249.51 & $8.63 \mathrm{E}-20$ \\
Cripple bad & 27 & 4771753 & 176731.6 & & \\
Total & 30 & $1.37 \mathrm{E}+08$ & & & \\
\hline
\end{tabular}

Table 8. Regression coefficient.

\begin{tabular}{lllllllll}
\hline & Coefficients & $\begin{array}{l}\text { Standard } \\
\text { error margin }\end{array}$ & t Stat & P-value & Lower 95\% & Upper 95\% & $\begin{array}{l}\text { Next limit } \\
\mathbf{9 5 . 0 \%}\end{array}$ & $\begin{array}{l}\text { Upper limit } \\
\mathbf{9 5 . 0 \%}\end{array}$ \\
\hline Intercept & 533.00914 & 136.0107 & 3.91888 & 0.00055 & 253.93828 & 812.08 & 253.9383 & 812.08 \\
X Variable 1 & $8.78 \mathrm{E}-06$ & $1.23 \mathrm{E}-06$ & 7.154818 & $1.08 \mathrm{E}-07$ & $6.26 \mathrm{E}-06$ & $1.13 \mathrm{E}-05$ & $6.26 \mathrm{E}-06$ & $1.13 \mathrm{E}-05$ \\
X Variable 2 & $-3.83 \mathrm{E}-15$ & $1.14 \mathrm{E}-15$ & -3.36164 & 0.002327 & $-6.17 \mathrm{E}-15$ & $-1.50 \mathrm{E}-15$ & $-6.20 \mathrm{E}-15$ & $-1.50 \mathrm{E}-15$ \\
X Variable 3 & 0.0556007 & 0.007264 & 7.654727 & $3.11 \mathrm{E}-08$ & 0.040697 & 0.070504 & 0.040697 & 0.070504 \\
\hline
\end{tabular}

Via detecting the regression model for the following pattern:

$$
L I F=533.009193+8.7756(E-06) I E T-3.83087(E-15) I E T^{2}+0.055600653 G D P^{0.9971}
$$




\section{The Output Value of Import and Export Trade and Elastic Effect of Fiscal Revenue}

(1).

Table 9. The import and export trade of fiscal income elasticity.

\begin{tabular}{|c|c|c|c|c|c|}
\hline num-ber & Provinces Cities & LIF & To predict $Y$ & Trade effect on revenue & Output value of fiscal revenue \\
\hline 1 & ShangHai & 5519.5 & 5050.136 & 0.629176 & 0.266906 \\
\hline 2 & PeiJing & 4723.9 & 4186.936 & 0.577527 & 0.29626 \\
\hline 3 & GuangDong & 9364.8 & 9420.317 & 0.5313 & 0.416029 \\
\hline 4 & ZheJiang & 4809.5 & 5430.842 & 0.477126 & 0.425699 \\
\hline 5 & JiangSu & 8028.6 & 7955.046 & 0.459989 & 0.474468 \\
\hline 6 & FuJian & 2544.1 & 3311.9 & 0.416071 & 0.423486 \\
\hline 7 & TianJin & 2667 & 2380.402 & 0.400901 & 0.375567 \\
\hline 8 & ShanDong & 5529.3 & 5823.112 & 0.326369 & 0.582594 \\
\hline 9 & ChongQing & 2155.1 & 2015.24 & 0.314034 & 0.421726 \\
\hline 10 & LiaoNing & 2125.6 & 2891.114 & 0.279317 & 0.536569 \\
\hline 11 & GuangXi & 1515.1 & 1881.053 & 0.233953 & 0.482856 \\
\hline 12 & JiangXi & 2165.5 & 1802.797 & 0.203036 & 0.501445 \\
\hline 13 & HeNan & 3009.6 & 3156.085 & 0.198853 & 0.632424 \\
\hline 14 & AnHui & 2454.2 & 2133.716 & 0.193293 & 0.557039 \\
\hline 15 & HeBei & 2648.5 & 2583.083 & 0.171084 & 0.622693 \\
\hline 16 & SiChuan & 3349.2 & 2598.979 & 0.170005 & 0.625033 \\
\hline 17 & HuBei & 3005.4 & 2519.899 & 0.155747 & 0.632842 \\
\hline 18 & Shanxi-1 & 2059.9 & 1779.139 & 0.14853 & 0.551977 \\
\hline 19 & YuNan & 1808.1 & 1487.825 & 0.143163 & 0.498678 \\
\hline 20 & HaiNan & 627.7 & 855.8004 & 0.142356 & 0.234905 \\
\hline 21 & XinJiang & 1331 & 1209.132 & 0.141687 & 0.417577 \\
\hline 22 & HeiLongJiang & 1165.2 & 1531.108 & 0.119272 & 0.532681 \\
\hline 23 & JiLin & 1229.3 & 1469.779 & 0.112214 & 0.525208 \\
\hline 24 & HuNan & 2515.8 & 2354.724 & 0.107974 & 0.665739 \\
\hline 25 & ShanXi-2 & 1642.2 & 1353.931 & 0.094848 & 0.511532 \\
\hline 26 & GuiZhou & 1503.3 & 1208.155 & 0.088336 & 0.470538 \\
\hline 27 & $\mathrm{GanSu}$ & 743.9 & 970.9761 & 0.072089 & 0.37901 \\
\hline 28 & NeiMeng & 1963.5 & 1618.817 & 0.068771 & 0.602012 \\
\hline 29 & NingXia & 373.7 & 724.4096 & 0.04586 & 0.218381 \\
\hline 30 & QingHai & 267.1 & 681.322 & 0.024851 & 0.192847 \\
\hline 31 & XiZang & 137.1 & 596.9242 & 0.01338 & 0.093702 \\
\hline
\end{tabular}

The above order of the financial income elasticity effect of import and export trade show that ShangHai import and export trade of most elastic effects of fiscal revenue, per $10 \%$ of the import and export trade, local fiscal revenue will be increased by $6.29 \%$; Import and export trade of fiscal income elasticity is larger in the first 10 provinces and cities in ShangHai, GuangDong, FuJian, TianJin in the column, in addition to this is BeiJing, ZheJiang, JiangSu, ShanDong, ChongQing, and LiaoNing province. This suggests that the increase of free trade on the regional economic development, fiscal revenue has played a significant role. One Belt And One Road, Yangtze river delta, the pearl river delta, the free trade area and so on construction has obtained the good effect. Under the state council recently added seven free trade area, we are looking forward to their higher achievements have been made for financial and economic development.

(2). GDP elasticity effect of fiscal revenue

In the import and export trade and production double factors for regional financial income, under the function of regional output value of fiscal income elasticity good see chart sorting, HuNan, HuBei, HeNan, SiChuan, HeBei, Inner Mongolia, ShanDong, AnHui, ShanXi-1 province and LiaoNing province, in the elastic function sort before ten, namely the provinces every $10 \%$ increase in output value, fiscal revenue will increase by more than $5 \%$, the highest was $6.66 \%$. Fiscal revenue, it seems these provinces is bigger to the dependence of the output. Regardless of the output is big, the role of fiscal revenue is small, economic development, the production value, create value and realize the value, is the subject of the economic and social development, there is no product value of production, its earnings on pure trade, only to the assignment of the business profits; Production and to create wealth, is the economic development of the entity, complete production to create value, trade value, is indispensable to finance increase and accumulate wealth two wheels. Stability of agriculture, industry, powerful, business development, business is strong to make the country strong.

\section{The Conclusion}

The above analysis shows that:

(1). Revenue is closely related to import and export

Import and export trade is scarce resources complement each other, It is the important form of the product sales, in the process of product, material transformation, realize the value of the economy. Make the product added value and profit, in the form of tax distribution in fiscal revenue, the business developed area is more significant in the free trade area, 
Import and export trade in the prosperity of the world economy at the same time, also make the local finance development effectively. Is based on this, in the near future in China is increasing the seven new free trade area, its effect on regional economic development, we will wait and see.

(2). The output value is the foundation of finance and economic growth

Fiscal revenue growth, not only limited to the growth of the sales link, product production, is the origin for wealth creation, is the entity of economic development, the realization of the GDP made economic development is the source of industrial, manufacturing, is the carrier of innovation, entrepreneurship, in expectation of regional financial resources at the same time, can't ignore the fundamental product value creation. To economic development, should adjust the relationship between the agricultural, industrial, commercial and service, the coordinated development of different industries, with the coordinated development of the industry within the supply and demand, don't make lame economic development. Attaches great importance to the import and export trade for the promotion of finance and economy, more attention should be paid to physical entity is the product of trade content. The third industry, of course, also made the economic development, it's only a matter of the structure of the trade.

(3). This article selects the limitations of economic indicators

The selected indicators have not fully endogenous, first of all, in terms of trade index, this article economy in the form of domestic trade to be ignored, its contribution to the fiscal and tax most comes from domestic consumption, this paper chose alone import and export trade, purpose is to emphasize alignment of regional finance and economy and international economy in our country, the world economic integration, don't deny that the role of domestic demand for finance and economy. Imports and exports, the article selected did not distinguish between imports and exports respectively to explain the fiscal revenue, blurring the import and export trade to optimize the role of fiscal revenue, it depends on the import and export tax breaks and leverage, so not to divide. This paper choose the GDP index does not consider the fine strokes of the first, second, third industry, did not distinguish between the industrial structure to the role of the local fiscal revenue, because its dilute the purpose of this paper to describe: import and export trade and fiscal and economic relations. Contact with accounting, main is to measure adopt trade accounting, budget accounting, economic output; Data analysis method using multiple regression, the empirical accounting method.

(4). Three factors in the construction of a comprehensive model with precision

Integrated regression model is the three elements in various provinces and cities in 2015 cross section data model structure of the whole samples test, on the basis of the statistical test is optimal, the empirical model of significance level is the highest. The application of the model not only can be used for content analysis factor index; Can also, according to the variable to predict the regularity of interdependence, to evaluate. Considering the space, the hybrid model prediction, evaluation of application shall be omitted.

(5). International trade and international economic development

Version based on the data analysis software of Excel, it widely exists in office software, Microsoft Excel 2003 edition and 2003 edition also has the data analysis function, and Stata, SPSS, Eviews, Minitab, such as simple operation, high work efficiency. Based on large data, cloud computing, the accounting information era, the function of accounting is not only limited to the simple information reflection of the accounting, accounting data and information service in macro forecast, decision-making is imperative.

Open trade policy, China will be helpful to domestic economic growth and the increase of the regional financial revenue, and the international economic development, economic prosperity made a positive contribution to the world.

\section{References}

[1] Li Shusheng. Study FDI impact on economic growth, employment of our country, based on the VAR model [J]. Journal of international trade issues. 2013 (04).

[2] Shang Jing, li-xinyu. China's foreign direct investment and industrial structure adjustment of the correlation analysis [J]. Journal of international trade issues.2012 (11).

[3] Wen-junzhao, jinpingyu. Open trade, FDI and economic growth of China's industrial mode, based on the research on 30 industry data $[\mathrm{J}]$. Journal of economic research. $2012(8)$.

[4] Wanghong, Mr Li Daokui, FengJunxin. FDI and independent research and development: based on the experience of the industry data research [J]. Journal of economic research. 2006 (02).

[5] Zhang Hang, Liu Yun. The Research Based on Big Data Management Accounting Model Building. ScienceLnnovation [J]. Science Publishing Group USA. Volume4 Numbrr4 August 2016:(04). PP:228-233.

[6] Gao Yan. China and "Hester," go hand in hand along the national trade and investment $[\mathrm{J}]$. international business accounting.2015 (3).

[7] Jin BaiSong, Liu JianYing. Grades 2015 and 2015, China's foreign trade outlook $[\mathrm{J}]$. international business accounting.2016 (03).

[8] Wang LiJuan, Mao LianCheng. Study on the relationship between the land competition between local governments, empirically based on the spatial autoregressive model [J]. Journal of finance review. 2012 (6).

[9] Wei LiLi, Li Chao, Li YuHui. Based on the nonlinear characteristics of RMB exchange rate and STAR model prediction [J]. Jstatistics and decision making.2014 (09).

[10] Lai Yong-jian,He Xiangmin. import and export trade of space nonlinear effects of inequality - smooth transition regression model based on panel[J]. Journal of Central University of Finance and Economics.2015(03).

[11] Qiu Ailian, AnYuMei. Import and export trade in liaoning province factors affecting the empirical analysis[J]. Journal of Shenyang University of Technology(Social Science Edition).2016(5) 